\title{
EVALUATION OF MECHANICAL PROPERTIES OF FLUORIDE- RELEASING DENTAL MATERIALS AFTER MULTIPLE FLUORIDE RECHARGE/DISCHARGE APPLICATION
}

\author{
AVALIAÇÃO DAS PROPRIEDADES MECÂNICAS DE MATERIAIS DENTÁRIOS \\ LIBERADORES DE FLÚOR APÓS APLICAÇÃO MÚLTIPLA DE \\ RECARGA/DESCARGA DE FLÚOR
}

\author{
Burak GÜMÜŞTAŞ ${ }^{1^{*}}$; Elif YAMAN DOSDOĞRU ${ }^{2}$; Sinan GÜNEYSU ${ }^{3}$ \\ 1. Department of Restorative Dentistry, Faculty of Dentistry, Istanbul Medipol University, Istanbul, Turkey; 2. Department of Pediatric \\ Dentistry, Faculty of Dentistry, Yeditepe University, Istanbul, Turkey; 3. Department of Environmental Engineering, Faculty of \\ Engineering, Istanbul University, Cerrahpasa. Corresponding author ${ }^{*}$.burakgu@gmail.com.
}

\begin{abstract}
This study aimed to determine the mechanical properties of fluoride-releasing dental materials after an accelerated fluoride recharge/discharge procedure. Two fluoride-releasing glass ionomer types of cement (Ketac Molar Easymix and IonoStar Molar), a resin-modified glass ionomer (Photac Fil Quick Aplicap), and two compomers (Compoglass F and Glasiosite) were used in this study. A total of 30 rectangular specimens and 30 disk specimens of each material were prepared and placed in distilled/deionized water $(\mathrm{n}=$ 5). The amount of fluoride released was analyzed from the materials for 7-day discharge, 1st recharge, 7-day discharge, 2nd recharge, and 7-day discharge, and 3rd recharge. The de/pre- and post-recharge fluoride release were measured using an ion chromatography for 24 days. The flexural strength and microhardness of each group were evaluated. The microhardness of all restorative materials showed no significant change $(p>0.05)$ over the experimental period. The flexural strength properties of the restorative materials did not change within the time of the study. The study showed that the fluoride release/uptake causes no effect on the mechanical and physical properties of dental materials.
\end{abstract}

KEYWORDS: Glass ionomer cement. Compomer. Resin-modified glass ionomer. Fluoride release. Microhardness.

\section{INTRODUCTION}

In the 1970s, Wilson and Kent have introduced the dental material "glass ionomer cement" (GICs). The GICs feature biological specifications, can adhere to the tooth structure by a chemical bond, and release fluoride ions that contribute caries-preventive properties (SIDHU, 2011; SHIOZAWA; TAKAHASHI; IWASAKI, 2014).

The rate of fluoride ion released from the GICs and compomers start rapidly and continually reduces at a fast rate after a short set period in an aqueous environment GICs and compomers can absorb fluoride from the environment, in a process called recharging, compensating for the loss of the fluoride ions (PRESTON et al., 2003; BANSAL; BANSAL, 2015). Although glass ionomer cements anti-caries efficacy has not shown by the randomized controlled clinical trials, this specification may provide dental materials the capability for lowering the dental caries lesions progression for a long service period. The compensation of lost fluoride ions by the uptake of

Received: 08/04/19

Accepted: 20/12/19 fluoride ions from the environment allows the dental material to act as a reservoir of fluoride ions (WIEGAND; BUCHALLA; ATTIN, 2007). Usually, the amount of fluoride released by dental materials declines severely after 3 days. Topical fluoride agents can be used for recharging the materials. This recharge capacity can change extensively among the different kinds of fluoridereleasing materials (XU; BURGESS, 2003; MARKOVIC; PETROVIC; PERIC, 2008).

The mechanical properties of glass ionomers, resin-modified glass ionomers (RMGI), and compomers are weaker than those of composite resins. Thus, the clinical application of dental materials is adequate for no-load-bearing areas. Several studies stated the relation among material fluoride release and mechanical properties (XU; BURGESS, 2003) Although several studies reported about fluoride release/recharge properties to evaluate material behavior in long storage period in aqueous environments (ELLAKURIA et al., 2003; PRESTON et al., 2003; SHIOZAWA;TAKAHASHI; IWASAKI, 2014), no study has researched about how multiple fluoride 
Evaluation of mechanical...

GUMUSTAS, B.; YAMAN DOSDOĞRU, E.; GÜNEYSU, S. release/recharge cycles affects the mechanical properties of fluoride-releasing materials using an accelerated recharge/discharge procedure without aging in water for a long time.

The hypotheses of the study were: (1) relatively high fluoride-releasing glass ionomers materials feature weaker mechanical properties than other fluoride-releasing RMGI and compomers; (2) high fluoride release/recharge characteristics cause a reduction in the mechanical properties of dental materials after an accelerated fluoride release/recharge procedure. In this study, the flexural strengths, microhardness, and fluoride release/recharge profiles of five commercial fluoride-releasing dental materials were examined. This study aimed to find the mechanical properties and fluoride release/recharge or how changes in the mechanical properties can occur after the fluoride release or recharge of five fluoride-releasing dental materials (two compomers, two conventional glass ionomers, and an RMGI) after an accelerated fluoride recharge/discharge procedure.

\section{MATERIAL AND METHODS}

\section{Specimen preparation}

Two GICs (Ketac Molar Easymix and IonoStar Molar), an RMGI (Photac Fil Quick Aplicap), and two compomers (Compoglass F and Glasiosite) were tested for comparison (Table 1). Specimens were fabricated for six test groups $(\mathrm{n}=$ $5)$ for six different observation times $\left(7^{\text {th }}(\mathrm{T} 1), 8^{\text {th }}\right.$ (T2), $15^{\text {th }}(\mathrm{T} 3), 16^{\text {th }}(\mathrm{T} 4), 23^{\text {rd }}(\mathrm{T} 5)$ and $24^{\text {th }}(\mathrm{T} 6)$ days).

Bar specimens were produced using a splittable stainless steel mold with dimensions of 2 x $2 \times 25 \mathrm{~mm}$ according to the ISO 4049 standard for the flexural strength test. All specimen materials were prepared, mixed, and dispensed according to the manufacturers' instructions. To determine the Vickers hardness and fluoride release, the disc specimens from each material set were prepared in a $5 \times 1 \mathrm{~mm}$ splittable stainless steel mold.

The materials were placed into the molds and covered with a glass coverslip. Compomer and RMGI specimens were cured utilizing an Elipar S10 curing light (3M ESPE, St. Paul MN, USA). The illumination cycle was set for $20 \mathrm{~s}$ per cycle with a minimum of three curing cycles on each exposed side of the bar specimens or $20 \mathrm{~s}$ per side of the disc specimens. The resulting extraneous flanges of the specimens were dressed in silicon carbide polishing paper (MicroCut PSA, 1200 grit, Buehler Ltd., IL, USA) at $45^{\circ}$. Thirty specimens were grouped for each material, and six groups $(n=5)$ were prepared and stored at $37^{\circ} \mathrm{C}$ in $5 \mathrm{ml}$ distilled/deionized water (Figure1).

\section{Fluoride release}

All the samples were stored in plastic vials for 7 days to ensure that the initial fluoride release "burst effect" had already transpired. The samples were transferred to new vials. The test specimens were immersed and stored in individual new plastic vials with $5 \mathrm{ml}$ deionized water changed daily at $37^{\circ} \mathrm{C}$ for 24 days. Activated charcoal was placed in the container with the same mass of the disk during the discharge of the materials for accelerating the discharging of the material which is used in water defluoridation systems (SIVASAMY et al., 2001).

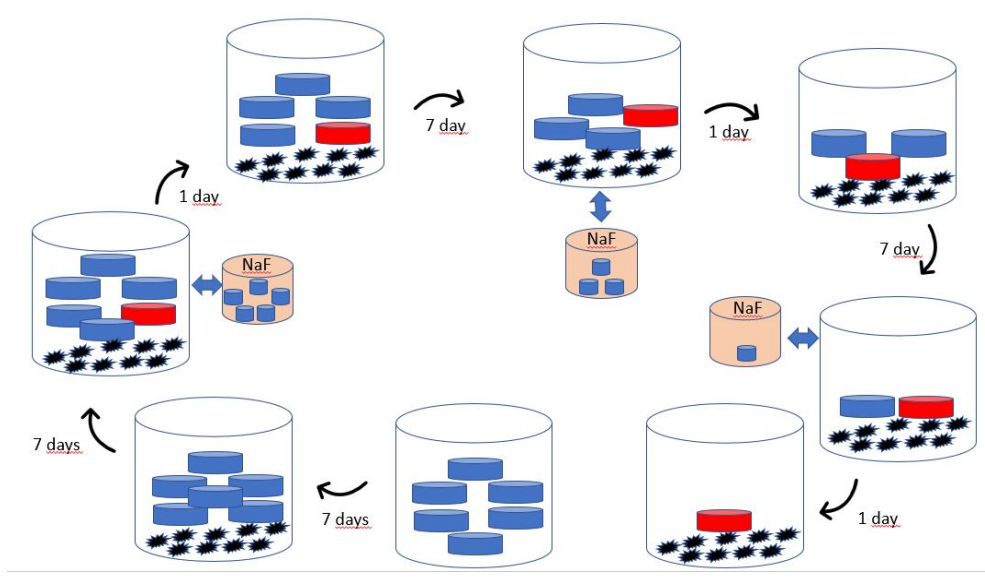

Figure 1. Methodology of the study 
Table 1. Materials used in this study

\begin{tabular}{|c|c|c|c|c|c|c|c|c|}
\hline \multirow{3}{*}{$\begin{array}{l}\text { Material - Color } \\
\text { Compoglass F } \\
\text { A2 }\end{array}$} & \multirow{3}{*}{$\begin{array}{l}\text { Code } \\
\text { C }\end{array}$} & \multicolumn{3}{|c|}{ Manufacturer - LOT } & \multirow[t]{2}{*}{ Type of Material } & \multicolumn{2}{|c|}{ Filler Load, Approx. } & \multirow{2}{*}{ Formulation } \\
\hline & & & & & & Mass & $\begin{array}{l}\text { Aver. } \\
\text { Vol } \%\end{array}$ & \\
\hline & & $\begin{array}{l}\text { VOCO } \\
\text { Germany } \\
\text { U24340 }\end{array}$ & $\mathrm{GmbH}$ & Cuxhaven, & Compomer & 77.3 & 1 & $\begin{array}{l}\mathrm{SiO}_{2}, \quad \mathrm{YbF}_{3},(\mathrm{Ba}) \mathrm{FAlSi}, \text { Bis- } \\
\text { GMA, UDMA, TEGDMA, } \\
\text { CDCDMA }\end{array}$ \\
\hline $\begin{array}{l}\text { Glasiosite } \\
\text { A2 }\end{array}$ & G & $\begin{array}{l}\text { VOCO } \\
\text { Germany } \\
\# 1529300\end{array}$ & $\mathrm{GmbH}$ & Cuxhaven, & Compomer & 77.5 & 0.7 & $\begin{array}{l}\mathrm{SiO}_{2} \text {, (Ba,B)AlSi, FAlSi, Bis- } \\
\text { GMA, UDMA }\end{array}$ \\
\hline $\begin{array}{l}\text { Photac Fil Quick Aplicap } \\
\text { A2 }\end{array}$ & $\mathrm{P}$ & $\begin{array}{l}\text { ESPE, Se } \\
\# 604128\end{array}$ & feld (Ger & any) & $\begin{array}{l}\text { Resin Modified Glass } \\
\text { Ionomer }\end{array}$ & $76 \%$ & $5-7 \mu \mathrm{m}$ & $\begin{array}{l}\text { Liquid: } \\
\text { methacrylate, polyethylene } \\
\text { polycarbonic acid, water, } \\
\text { diurethane dimethacrylate, } \\
\text { magnesium hema ester. Powder: } \\
\text { Silane-treated glass powder, N, } \\
\text { N-dimethyl benzocaine }\end{array}$ \\
\hline $\begin{array}{l}\text { Ketac Molar Easymix } \\
\text { A2 }\end{array}$ & $\mathrm{K}$ & $\begin{array}{l}\text { 3M ESPE } \\
\# 617827\end{array}$ & Seefeld, & ermany & Glass Ionomer & 74 & $2-3$ & $\begin{array}{l}\text { Al-Ca-La fluorosilicate glass, } 5 \\
\% \text { copolymer acrylic, and } \\
\text { maleic acid }\end{array}$ \\
\hline $\begin{array}{l}\text { IonoStar Molar } \\
\text { A2 }\end{array}$ & I & $\begin{array}{l}\text { Voco Gm } \\
\text { Cuxhaven } \\
\# 1509280\end{array}$ & $\begin{array}{l}\text { H, } \\
\text { Germany }\end{array}$ & & Glass Ionomer & - & - & $\begin{array}{l}\text { Polyacrylic and tartaric acid, } \\
\text { fluorosilicate }\end{array}$ \\
\hline
\end{tabular}


The specimens were kept in a shaker machine (Stuart Microtiter shaker incubator SI505, Bibby Scientific, Stone, United Kingdom). The fluoride concentration of the storage water was measured by Ion-Chromatography (IC) (DX 100, Dionex, Camberley, UK-IC), and the results of fluoride release were calculated as the amount of fluoride released per unit surface area of the specimen $\left(\mathrm{mg} / \mathrm{cm}^{2}\right)$. For measurement, IC with suppressed conductivity was used for free fluoride ion determination. The instrument was fitted with an IonPac AS14 analytical column (Dionex) and IonPac AG14 guard column (Dionex). The loop was designed such that $250 \mathrm{ml}$ volume was fed to the column for analysis. A flow rate of $1.0 \mathrm{ml} / \mathrm{min}$ was used. Free fluoride ions feature a well-defined retention time, and the peak corresponding to fluoride could readily be determined from the chromatogram. The peak area was used to determine the fluoride concentrations by linear interpolation between the standard solutions with concentrations slightly higher and lower than that of the test solution.

On day 7, 15, and 23 specimens were soaked for $4 \mathrm{~min}$ in a neutral sodium fluoride gel 2\% (9000 ppm) (Sultan Topex neutral pH gel, Sultan Dental Products, USA) for recharging the materials. After this "recharging," the specimens were rinsed with copious amounts of distilled/deionized water, shaken dry, and transferred to a new container with $5 \mathrm{ml}$ distilled/deionized water. The daily fluoride release for before and 1 day after recharging were determined using IC as described above. The amount of fluoride released per unit surface area of the specimen $\left(\mathrm{mg} / \mathrm{cm}^{2}\right)$ was calculated at each time point, and the amount of fluoride recharge was indicated by the difference in the fluoride release during the $24 \mathrm{~h}$ period before and after recharging.

\section{Flexural strength}

Flexural strength tests were performed in a universal testing machine (AG-X, Shimadzu Corp., Kyoto, Japan). In the testing machine, the specimens were placed in a specimen holder with two cylindrical supports measuring $1 \mathrm{~mm}$ in diameter. The supports were separated by a $20 \mathrm{~mm}$ gap. The radius of the bending piston was $1 \mathrm{~mm}$, and a force was applied at a crosshead speed of $1 \mathrm{~mm} / \mathrm{min}$; the results were recorded until failure. For each set of specimens, the fracture force represented the mean value of six measurements. The flexural strength values $(\sigma)$ in $\mathrm{MPa}$ were calculated by using the formula below:

$$
\sigma=3 \mathrm{PL} / 2 \mathrm{wb}^{2}
$$

where $\mathrm{P}$ refers to the fracture load (in Newton), L denotes the distance between the supports, and $\mathrm{w}$ and $\mathrm{b}$ correspond to the width and height of the specimen, respectively (all in $\mathrm{mm}$ ).

\section{Microhardness}

The Vickers hardness was determined with the application of a $100 \mathrm{~g}$ load for $20 \mathrm{~s}$ (Shimadzu, HMV-2000, Japan). Three values were recorded for each specimen in randomly taken (ELLAKURIA et al., 2003).

\section{Statistical analysis}

The mean values and standard deviations were estimated. The data were subjected to the Shapiro-Wilk normality test. For comparison of different groups at the same time of collection: the flexural strength, the microhardness, and fluoride release data were analyzed with nonparametric Kruskal-Wallis and multiple comparisons by Mann-Whitney U tests; the analyses were carried out with SPSS 22.0 (SPSS Inc., Chicago, Ill, USA). For comparison of different collection times within each group: The Friedman test was used for nonnormal distribution data, and the Wilcoxon test was used for further analysis. The level of significance was set at $p=0.05$.

\section{RESULTS}

Table 2 shows the data recorded from the mean flexural strength tests of each material after storage in deionized water for 7-day discharge (T1), 1st recharge (T2), 7-day discharge (T3), 2nd recharge (T4), 7-day discharge (T5) and 3rd recharge (T6). The flexural strength properties of the restorative materials did not change within the time of the study $(p>0.05)$. At T1, the Glasiosite group yielded the highest flexural strength (55.8MPa), followed in descending order by Compoglass, Photac Fil, Ketac Molar, and IonoStar (Table 2). The microhardness of all restorative materials showed no significant change $(\mathrm{p}>0.05)$ over the experimental period (Table 3). All restorative materials continually released fluoride throughout the experimental period (Table 4). There is no significant difference for fluoride release of the Glasiosite group within the time of the study $(\mathrm{p}>$ $0.05)$. 
Table 2. Flexural Strength values of the materials in the study

\begin{tabular}{|c|c|c|c|c|c|c|}
\hline & Compoglass & Glasiosite & Photac Fil & Ketac Molar & IonoStar & \\
\hline $\begin{array}{l}\text { Flexural } \\
\text { Strength }\end{array}$ & $\begin{array}{l}\text { Mean } \pm \text { SD } \\
\text { (Median) }\end{array}$ & $\begin{array}{l}\text { Mean } \pm \text { SD } \\
\text { (Median) }\end{array}$ & $\begin{array}{l}\text { Mean } \pm \text { SD } \\
\text { (Median) }\end{array}$ & $\begin{array}{l}\text { Mean } \pm \text { SD } \\
\text { (Median) }\end{array}$ & $\begin{array}{l}\text { Mean } \pm \text { SD } \\
\text { (Median) }\end{array}$ & $\mathrm{p}^{1}$ \\
\hline T1 & $\begin{array}{l}53,84 \pm 5,48 \mathrm{aA} \\
(54)\end{array}$ & $\begin{array}{l}55,8 \pm 8,06 \mathrm{aB} \\
(54,2)\end{array}$ & $\begin{array}{l}41,58 \pm 5,69 \mathrm{bC} \\
(43,7)\end{array}$ & $\begin{array}{l}50,94 \pm 8,57 \mathrm{aD} \\
(48,5)\end{array}$ & $\begin{array}{l}35,62 \pm 5,75 \mathrm{cE} \\
(37,5)\end{array}$ & $\begin{array}{l}0,00 \\
4 *\end{array}$ \\
\hline T2 & $\begin{array}{l}48,54 \pm 4,31 \mathrm{aA} \\
(46)\end{array}$ & $\begin{array}{l}52,78 \pm 1,98 \mathrm{aB} \\
(52,95)\end{array}$ & $\begin{array}{l}42,71 \pm 3,42 b C \\
(43,2)\end{array}$ & $\begin{array}{l}49,19 \pm 7,6 \mathrm{aD} \\
(49,55)\end{array}$ & $\begin{array}{l}41,53 \pm 6,96 \mathrm{bE} \\
(41,8)\end{array}$ & $\begin{array}{l}\mathbf{0 , 0 2} \\
0 *\end{array}$ \\
\hline T3 & $\begin{array}{l}49,35 \pm 6,03 \mathrm{aA} \\
(49,7)\end{array}$ & $\begin{array}{l}52,19 \pm 2,69 \mathrm{aB} \\
(52,2)\end{array}$ & $\begin{array}{l}40,9 \pm 4,27 \mathrm{bC} \\
(40,6)\end{array}$ & $\begin{array}{l}48,25 \pm 7,51 \mathrm{aD} \\
(46,3)\end{array}$ & $\begin{array}{l}44,8 \pm 4,06 \mathrm{bE} \\
(45,2)\end{array}$ & $\begin{array}{l}\mathbf{0 , 0 3} \\
7 *\end{array}$ \\
\hline T4 & $\begin{array}{l}47,71 \pm 3,41 \mathrm{aA} \\
(46,75)\end{array}$ & $\begin{array}{l}52,29 \pm 3,02 \mathrm{aB} \\
(52,6)\end{array}$ & $\begin{array}{l}39,83 \pm 3,03 \mathrm{bC} \\
(39,05)\end{array}$ & $\begin{array}{l}47,6 \pm 5,1 \mathrm{aD} \\
(48,75)\end{array}$ & $\begin{array}{l}44,32 \pm 8,32 \mathrm{bE} \\
(44,25)\end{array}$ & $\begin{array}{l}\mathbf{0 , 0 2} \\
6^{*}\end{array}$ \\
\hline T5 & $\begin{array}{l}48,22 \pm 3,68 \mathrm{aA} \\
(45,8)\end{array}$ & $\begin{array}{l}51,63 \pm 2,95 \mathrm{aB} \\
(50,7)\end{array}$ & $\begin{array}{l}39,55 \pm 8,54 \mathrm{aC} \\
(40)\end{array}$ & $\begin{array}{l}46,42 \pm 4,59 \mathrm{aD} \\
(47)\end{array}$ & $\begin{array}{l}45,94 \pm 5,57 \mathrm{aE} \\
(47,15)\end{array}$ & $\begin{array}{l}0,10 \\
3\end{array}$ \\
\hline T6 & $\begin{array}{l}48,28 \pm 3,14 \mathrm{aA} \\
(49,05)\end{array}$ & $\begin{array}{l}51,14 \pm 5,52 \mathrm{aB} \\
(50,05)\end{array}$ & $\begin{array}{l}39,81 \pm 7,94 \mathrm{aC} \\
(36,65)\end{array}$ & $\begin{array}{l}44,22 \pm 3,29 \mathrm{aD} \\
(45,7)\end{array}$ & $\begin{array}{l}46,53 \pm 8,27 \mathrm{aE} \\
(42,85)\end{array}$ & $\begin{array}{l}0,10 \\
8\end{array}$ \\
\hline$p^{2}$ & 0,475 & 0,979 & 0,535 & 0,402 & 0,208 & \\
\hline
\end{tabular}

Table 3. Vickers microhardness values of the materials in the study

\begin{tabular}{|c|c|c|c|c|c|c|}
\hline \multirow[b]{2}{*}{$\begin{array}{l}\text { Microhard } \\
\text { ness }\end{array}$} & Compoglass & Glasiosite & Photac Fil & Ketac Molar & IonoStar & \multirow[t]{2}{*}{$p^{1}$} \\
\hline & $\begin{array}{l}\text { Mean } \pm \text { SD } \\
\text { (Median) }\end{array}$ & $\begin{array}{l}\text { Mean } \pm \text { SD } \\
\text { (Median) }\end{array}$ & $\begin{array}{l}\text { Mean } \pm \text { SD } \\
\text { (Median) }\end{array}$ & $\begin{array}{l}\text { Mean } \pm \text { SD } \\
\text { (Median) }\end{array}$ & $\begin{array}{l}\text { Mean } \pm \text { SD } \\
\text { (Median) }\end{array}$ & \\
\hline T1 & $\begin{array}{l}58,42 \pm 3,99 \mathrm{aA} \\
(58,44)\end{array}$ & $\begin{array}{l}62,27 \pm 4,79 \mathrm{aB} \\
(62,19)\end{array}$ & $\begin{array}{l}46,08 \pm 2,99 b C \\
(45,29)\end{array}$ & $\begin{array}{l}39,94 \pm 1,19 \mathrm{cD} \\
(39,61)\end{array}$ & $\begin{array}{l}38,55 \pm 2,05 \mathrm{cE} \\
(38,26)\end{array}$ & $\begin{array}{l}\mathbf{0 , 0 0} \\
0 *\end{array}$ \\
\hline $\mathbf{T 2}$ & $\begin{array}{l}53,07 \pm 2,14 \mathrm{bA} \\
(53,63)\end{array}$ & $\begin{array}{l}57,64 \pm 1,55 \mathrm{aB} \\
(57,19)\end{array}$ & $\begin{array}{l}44,67 \pm 1,47 \mathrm{cC} \\
(45,1)\end{array}$ & $\begin{array}{l}40,45 \pm 1,03 \mathrm{dD} \\
(40,45)\end{array}$ & $\begin{array}{l}40,1 \pm 2,43 \mathrm{dE} \\
(40,68)\end{array}$ & $\begin{array}{l}\mathbf{0 , 0 0} \\
0^{*}\end{array}$ \\
\hline T3 & $\begin{array}{l}52,36 \pm 4,38 \mathrm{bA} \\
(51,79)\end{array}$ & $\begin{array}{l}60,09 \pm 1,13 \mathrm{aB} \\
(60,53)\end{array}$ & $\begin{array}{l}45,71 \pm 3,23 \mathrm{cC} \\
(45,93)\end{array}$ & $\begin{array}{l}40,62 \pm 0,94 \mathrm{dD} \\
(40,73)\end{array}$ & $\begin{array}{l}41,23 \pm 1,67 \mathrm{dE} \\
(40,8)\end{array}$ & $\begin{array}{l}\mathbf{0 , 0 0} \\
0^{*}\end{array}$ \\
\hline T4 & $\begin{array}{l}51,99 \pm 2,85 \mathrm{bA} \\
(53,09)\end{array}$ & $\begin{array}{l}58,33 \pm 3,1 \mathrm{aB} \\
(58,27)\end{array}$ & $\begin{array}{l}46,35 \pm 1,06 \mathrm{cC} \\
(46,82)\end{array}$ & $\begin{array}{l}40,2 \pm 2,91 \mathrm{dD} \\
(40,53)\end{array}$ & $\begin{array}{l}41,83 \pm 2,35 \mathrm{dE} \\
(41,21)\end{array}$ & $\begin{array}{l}\mathbf{0 , 0 0} \\
0^{*}\end{array}$ \\
\hline T5 & $\begin{array}{l}50,84 \pm 4,18 \mathrm{bA} \\
(48,8)\end{array}$ & $\begin{array}{l}59,45 \pm 1,54 \mathrm{aB} \\
(59,39)\end{array}$ & $\begin{array}{l}45,44 \pm 1,59 \mathrm{cC} \\
(45,46)\end{array}$ & $\begin{array}{l}40,71 \pm 2,88 \mathrm{dD} \\
(39,09)\end{array}$ & $\begin{array}{l}42,02 \pm 3,31 \mathrm{dE} \\
(41,47)\end{array}$ & $\begin{array}{l}\mathbf{0 , 0 0} \\
\mathbf{0}^{*}\end{array}$ \\
\hline T6 & $\begin{array}{l}50,64 \pm 3,66 \mathrm{bA} \\
(49,83)\end{array}$ & $\begin{array}{l}59,32 \pm 3,19 \mathrm{aB} \\
(58,39)\end{array}$ & $\begin{array}{l}45,33 \pm 1,28 \mathrm{cC} \\
(45,62)\end{array}$ & $\begin{array}{l}40,72 \pm 0,97 \mathrm{dD} \\
(40,5)\end{array}$ & $\begin{array}{l}42,6 \pm 4,15 \mathrm{dE} \\
(43,66)\end{array}$ & $\begin{array}{l}\mathbf{0 , 0 0} \\
\mathbf{0} * \\
\end{array}$ \\
\hline $\mathbf{p}^{2}$ & 0,303 & 0,262 & 0,861 & 0,905 & 0,105 & \\
\hline
\end{tabular}

Table 4. Fluoride release values of the materials in the study

\begin{tabular}{|c|c|c|c|c|c|c|}
\hline & Compoglass & Glasiosite & Photac Fil & Ketac Molar & IonoStar & \\
\hline $\begin{array}{l}\text { Fiuoride } \\
\text { Release }\end{array}$ & $\begin{array}{l}\text { Mean } \pm \text { SD } \\
\text { (Median) }\end{array}$ & $\begin{array}{l}\text { Mean } \pm \text { SD } \\
\text { (Median) }\end{array}$ & $\begin{array}{l}\text { Mean } \pm \text { SD } \\
\text { (Median) }\end{array}$ & $\begin{array}{l}\text { Mean } \pm \text { SD } \\
\text { (Median) }\end{array}$ & $\begin{array}{l}\text { Mean } \pm \text { SD } \\
\text { (Median) }\end{array}$ & $\mathbf{p}^{1}$ \\
\hline T1 & $\begin{array}{l}0,27 \pm 0,07 \mathrm{bB} \\
(0,24)\end{array}$ & $\begin{array}{l}0,2 \pm 0,33 \mathrm{bA} \\
(0,06)\end{array}$ & $\begin{array}{l}3,33 \pm 0,59 \mathrm{aB} \\
(3,14)\end{array}$ & $\begin{array}{l}2,53 \pm 0,69 \mathrm{aA} \\
(2,35)\end{array}$ & $\begin{array}{l}3,53 \pm 0,26 \mathrm{aA} \\
(3,46)\end{array}$ & $\begin{array}{l}0,00 \\
1 *\end{array}$ \\
\hline T2 & $\begin{array}{l}2,4 \pm 0,55 \mathrm{cA} \\
(2,4)\end{array}$ & $\begin{array}{l}0,33 \pm 0,22 \mathrm{eA} \\
(0,22)\end{array}$ & $\begin{array}{l}6,19 \pm 0,74 \mathrm{aA} \\
(6,2)\end{array}$ & $\begin{array}{l}1,6 \pm 0,23 \mathrm{~dB} \\
(1,53)\end{array}$ & $\begin{array}{l}4,01 \pm 0,73 \mathrm{bA} \\
(4,35)\end{array}$ & $\begin{array}{l}\mathbf{0 , 0 0} \\
\mathbf{0}^{*}\end{array}$ \\
\hline T3 & $\begin{array}{l}0,6 \pm 0,17 \mathrm{aB} \\
(0,65)\end{array}$ & $\begin{array}{l}0,2 \pm 0,15 \mathrm{cA} \\
(0,12)\end{array}$ & $\begin{array}{l}0,9 \pm 0,12 \mathrm{aD} \\
(0,88)\end{array}$ & $\begin{array}{l}0,36 \pm 0,1 \mathrm{bC} \\
(0,33)\end{array}$ & $\begin{array}{l}0,47 \pm 0,54 \mathrm{bC} \\
(0,29)\end{array}$ & $\begin{array}{l}\mathbf{0 , 0 0} \\
7 *\end{array}$ \\
\hline T4 & $\begin{array}{l}1,98 \pm 0,64 \mathrm{bA} \\
(2,23)\end{array}$ & $\begin{array}{l}0,3 \pm 0,23 \mathrm{cA} \\
(0,3)\end{array}$ & $\begin{array}{l}2,45 \pm 0,36 a \\
(2,26)\end{array}$ & $\begin{array}{c}\text { C } 1,16 \pm 0,4 \mathrm{bB} \\
(1,27)\end{array}$ & $\begin{array}{l}1,37 \pm 0,5 \mathrm{bB} \\
(1,19)\end{array}$ & $\begin{array}{l}0,00 \\
2 *\end{array}$ \\
\hline
\end{tabular}




\begin{tabular}{lllllll} 
T5 & $0,33 \pm 0,08 \mathrm{bB}$ & $0,18 \pm 0,09 \mathrm{aA}$ & $0,9 \pm 0,36 \mathrm{aD}$ & $0,36 \pm 0,08 \mathrm{bC}$ & $0,36 \pm 0,27 \mathrm{bC}$ & $\mathbf{0 , 0 0}$ \\
& $(0,38)$ & $(0,2)$ & $(0,79)$ & $(0,36)$ & $(0,29)$ & $\mathbf{6}^{*}$ \\
T6 & $2,29 \pm 0,33 \mathrm{aA}$ & $0,37 \pm 0,06 \mathrm{cA}$ & $1,94 \pm 0,27 \mathrm{aC}$ & $1,34 \pm 0,49 \mathrm{bB}$ & $1,52 \pm 0,78 \mathrm{bB}$ & $\mathbf{0 , 0 0}$ \\
& $(2,27)$ & $(0,39)$ & $(1,85)$ & $(1,47)$ & $(1,2)$ & $\mathbf{2}^{*}$ \\
\hline $\mathbf{p}^{\mathbf{2}}$ & $\mathbf{0 , 0 0 1}{ }^{*}$ & $\mathbf{0 , 1 6 4}$ & $\mathbf{0 , 0 0 0 ^ { * }}$ & $\mathbf{0 , 0 0 1 *}$ & $\mathbf{0 , 0 0 1 *}$ & \\
\hline
\end{tabular}

The values within the same lowercase letter group have no significant difference in line, the values within the same uppercase letter group have no significant difference in the column.

\section{DISCUSSION}

This study determined the effect of repetitive fluoride uptake and release on the mechanical properties and fluoride release rates of commercial restorative materials. Both the null hypotheses were rejected according to the results of this study. The mechanical properties of all restorative materials decreased with storage in water, but it is not statistically significant and has not influenced the fluoride release/recharge characteristics. However, the repetitive fluoride release and uptake caused a minimal effect on the mechanical properties of the restorative materials after aging.

The fluoride release and uptake characteristics of fluoride-releasing materials were tested with numerous in vitro studies (PRESTON et al., 2003; NEELAKANTAN et al., 2011; SIDHU, 2011; DIONYSOPOULOS et al., 2013; MUNGARA et al., 2013; BANSAL; BANSAL, 2015). However, limited studies reported about how the physical properties of dental materials are affected by fluoride release and uptake. The fluoroaluminosilicate glass particles directly determine the mechanical properties and will also release fluoride to the oral environment. The particle size of the material directly alters the fluoride release. Smaller particles causing surface area growth concludes the increased interaction with the environment (DE CALUWÉ et al., 2014).

The methodologies used for the fluoride release calculation include keeping in deionized water, sterilized saliva, artificial saliva, saline solution, and $\mathrm{pH}$ cycling systems (LEVALLOIS et al., 1998; MCKENZIE; LINDEN; NICHOLSON, 2003; NAOUM et al., 2011; SHIOZAWA; TAKAHASHI; IWASAKI, 2014). The decrease in medium $\mathrm{pH}$ causes more fluoride ion release, and this condition can be explained by acidic ions in media attacking the restorative material, resulting in material dissolution (GANDOLFI et al., 2006; WIEGAND; BUCHALLA; ATTIN, 2007).

However, fluoride dissolution in a neutral medium is less than that in an acidic medium; this event can be explained by diffusion of the fluoride ions from the material to the medium until the medium saturation. In our study, the deionized water medium to release glass ionomer restorative materials fluoride ion to not deteriorate the materials mechanic properties (MCKENZIE; LINDEN; NICHOLSON, 2003; GANDOLFI et al., 2006). The fluoride release can be measured using an ionselective electrode, which measures the total fluoride ion released (free and complex-in acidic $\mathrm{pH}$ ), or IC, which measures the concentration of free fluoride ions (MCCABE; CARRICK; SIDHU, 2002). Using fluoride adsorbents in the medium prevents the medium from becoming saturated without changing the medium $\mathrm{pH}$ (MEENAKSHI; MAHESHWARI, 2006; MOREAU; XU, 2010). For defluoridation, different types of fluoride adsorbents are used, e.g., chemically activated carbon, activated alumina, coconut shell carbon, bone charcoal, natural zeolites, burned clay, and other adsorbents (SIVASAMY et al., 2001; MEENAKSHI; MAHESHWARI, 2006; YADAV et al., 2006). In the present study, chemically activated carbon particles were used in distilled water, with the mass measuring as much as that of the disk specimen.

The hardness and elastic modulus are fundamental mechanical properties of restorative materials. Hardness refers to the plastic deformation of restoratives under occlusal stress and relates to functional parameters, such as resistance to deformation, friction, and abrasion (SILVA et al., 2007; GARCIA-CONTRERAS et al., 2015). Several studies reported that by releasing fluoride ions from the material, certain mechanical properties could be altered (WILDE et al., 2006; WANG et al., 2007; MOREAU; XU, 2010). Magni et al. (2010) reported that the Vickers microhardness of Photac Fil is $46.2 \mathrm{VH}$, which is similar to our results. Our study showed that all the restorative materials showed a reduction in microhardness with the fluoride release although the values showed no statistical significance $(p<0.05)$. The IonoStar Molar group showed a continuous increase in microhardness, which can be explained by the material setting reaction that continued within a week. 
In this study, a three-point bending test was used to measure the flexural strength of the materials. This commonly used test is designed as the primary strength test for resin-containing dental restorative materials under the international testing standards (GLADYS et al., 1997; XIE et al., 2000). The lowest flexural strength value was measured in glass ionomers (IonoStar Molar and Ketac Molar Easymix), whereas the highest value was demonstrated for the compomers (Glasiosite and Compoglass). This finding was not unexpected, as prior studies have demonstrated that GICs are brittle materials with low flexural strength, whereas compomer materials have previously demonstrated high flexural strength (XIE et al., 2000; ILIE et al., 2012). For Ketac Molar Easymix, the reported strength values of Bonifacio et al. (BONIFÁCIO et al., 2009) were similar to those of our study. This finding can be explained by the uptake or release of fluoride ions that occurred in the glass particle-free surface or mobility of unbounded fluoride ions in the material matrix.

Although compomers are mechanically stronger than glass ionomers and RMGIs, their capability to release fluoride ions make such materials a desirable option, especially in high-risk caries patients (XU AND BURGESS, 2003; CURY et al., 2016). The first 7 days of storage in distilled water were excluded in the experiment to prevent altering the results with the "burst effect." The Photac Fil group is the most fluoride-releasing material, whereas the least fluoride-releasing materials include both the GICs. This finding could be explained by the incomplete use of Photac Fil's filler particles in material setting reaction, resulting in an increased area of the particles.

The main limitations of this study are the limited sample size and using distilled water for materials fluoride release medium could not mimic clinical conditions as artificial saliva. The accelerated fluoride discharge process was conducted using activated charcoal instead of a cariogenic challenge which again not simulating an in vitro reproducible clinical condition.

The present study showed that the fluoride release/uptake causes no effect on the mechanical and physical properties of restorative dental materials. Therefore, decreasing the fluoride released by frequent external application of fluoride could be achieved. Further studies should be conducted to determine how the materials release fluoride and their uptake mechanisms. In conclusion, the composition of glass ionomer cement plays a major role in determining the fluoride release or recharging capabilities of materials. The selection of materials for clinical use will depend on the material's fluoride recharging capability. Thus, this property will be a significant factor as the release of fluoride ions within the material will be much greater after recharging the material with fluoride gel.

RESUMO: Este estudo teve como objetivo determinar as propriedades mecânicas de materiais dentários liberadores de flúor após um procedimento acelerado de recarga/descarga de flúor. Dois tipos de cimento de ionômero de vidro liberador de flúor (Ketac Molar Easymix e IonoStar Molar), um ionômero de vidro modificado por resina (Photac Fil Quick Aplicap) e dois compômeros (Compoglass F e Glasiosite) foram utilizados neste estudo. Um total de 30 amostras retangulares e 30 amostras de disco de cada material foram preparadas e colocadas em água destilada/deionizada $(n=5)$. A quantidade de fluoreto liberado foi analisada a partir dos materiais para descarga em 7 dias, $1^{\mathrm{a}}$ recarga, descarga em 7 dias, $2^{\mathrm{a}}$ recarga e descarga em 7 dias e $3^{\mathrm{a}}$ recarga. A liberação de fluoreto pré e pós-recarga foi medida usando uma cromatografia de íons por 24 dias. A resistência à flexão e a microdureza de cada grupo foram avaliadas. A microdureza de todos os materiais restauradores não apresentou alteração significativa $(\mathrm{p}>0,05)$ durante o período experimental. As propriedades de resistência à flexão dos materiais restauradores não mudaram no período do estudo. $\mathrm{O}$ estudo mostrou que a liberação/captação de flúor não afeta as propriedades mecânicas e físicas dos materiais dentários.

PALAVRAS-CHAVE: Cimento de ionômero de vidro. Compômero. Ionômero de vidro modificado com resina. Liberação de flúor. Microdureza.

\section{REFERENCES}

BANSAL, R.; BANSAL, T. A Comparative Evaluation of the Amount of Fluoride Release and Re-Release after Recharging from Aesthetic Restorative Materials: An in vitro Study. Journal Of Clinical And Diagnostic Research, v. 9, n. 8, p. ZC11-4, 2015. https://doi.org/10.7860/JCDR/2015/11926.6278 
BONIFÁCIO, C. C.; KLEVERLAAN, C. J.; RAGGIO, D. P.; WERNER, A.; DE CARVALHO, R. C. R.; VAN AMERONGEN, W. E. Physical-mechanical properties of glass ionomer cements indicated for atraumatic restorative treatment. Australian Dental Journal, v. 54, n. 3, p. 233-237, 2009. https://doi.org/10.1111/j.18347819.2009.01125.x

CURY, J. A.; DE OLIVEIRA, B. H.; DOS SANTOS, A. P. P.; TENUTA, L. M. A. Are fluoride releasing dental materials clinically effective on caries control? Dental Materials, v. 32, n. 3, p. 323-333, 2016 https://doi.org/10.1016/j.dental.2015.12.002

DE CALUWÉ, T.; VERCRUYSSE, C. W. J.; FRAEYMAN, S.; VERBEECK, R. M. H. The influence of particle size and fluorine content of aluminosilicate glass on the glass ionomer cement properties. Dental Materials, v. 30, n. 9, p. 1029-1038, 2014. https://doi.org/10.1016/j.dental.2014.06.003

DIONYSOPOULOS, D.; KOLINIOTOU-KOUMPIA, E.; HELVATZOGLOU-ANTONIADES, M.; KOTSANOS, N. Fluoride release and recharge abilities of contemporary fluoride-containing restorative materials and dental adhesives. Dental Materials Journal, v. 32, n. 2, p. 296-304, 2013.

https://doi.org/10.4012/dmj.2012-144

ELLAKURIA, J.; TRIANA, R.; MINGUEZ, N.; SOLER, I.; IBASETA, G.; MAZA, J.; GARCIA-GODOY, F. Effect of one-year water storage on the surface microhardness of resin-modified versus conventional glassionomer cements. Dental Materials, v. 19, n. 4, p. 286-290, 2003. https://doi.org/10.1016/S01095641(02)00042-8

GANDOLFI, M. G.; CHERSONI, S.; ACQUAVIVA, G. L.; PIANA, G.; PRATI, C.; MONGIORGI, R. Fluoride release and absorption at different pH from glass-ionomer cements. Dental Materials, v. 22, n. 5, p. 441-449, 2006. https://doi.org/10.1016/j.dental.2005.04.036

GARCIA-CONTRERAS, R.; SCOUGALL-VILCHIS, R. J.; CONTRERAS-BULNES, R.; SAKAGAMI, H.; MORALES-LUCKIE, R. A.; NAKAJIMA, H. Mechanical, antibacterial and bond strength properties of nanotitanium-enriched glass ionomer cement. Journal of Applied Oral Science, v. 23, n. 3, p. 321-328, 2015 https://doi.org/10.1590/1678-775720140496

GLADYS, S.; VAN MEERBEEK, B.; BRAEM, M.; LAMBRECHTS, P.; VANHERLE, G. Comparative physicomechanical characterization of new hybrid restorative materials with conventional glass-ionomer and resin composite restorative materials. Journal of Dental Research, v. 76, n. 4, p. 883-894, 1997. https://doi.org/10.1177/00220345970760041001

ILIE, N.; HICKEL, R.; VALCEANU, A. S.; HUTH, K. C. Fracture toughness of dental restorative materials. Clinical Oral Investigations, v. 16, n. 2, p. 489-498, 2012. https://doi.org/10.1007/s00784-011-0525-z

LEVALLOIS, B.; FOVET, Y.; LAPEYRE, L.; GAL, J. Y. In vitro fluoride release from restorative materials in water versus artificial saliva medium (SAGF). Dental Materials, v. 14, n. 6, p. 441-447, 1998. https://doi.org/10.1016/S0300-5712(99)00019-6

MAGNI, E.; FERRARI, M.; HICKEL, R.; ILIE, N. Evaluation of the mechanical properties of dental adhesives and glass-ionomer cements. Clinical oral investigations, v. 14, n. 1, p. 79-87, 2010. https://doi.org/10.1007/s00784-009-0259-3

MARKOVIC, D. L.; PETROVIC, B. B.; PERIC, T. O. Fluoride content and recharge ability of five glassionomer dental materials. BMC Oral Health, v. 8, n. 1, p. 21, 2008. https://doi.org/10.1186/1472-6831-821 
MCCABE, J. F.; CARRICK, T. E.; SIDHU, S. K. Determining low levels of fluoride released from resin-based dental materials. European Journal of Oral Sciences, v. 110, n. 5, p. 380-384, 2002.

https://doi.org/10.1034/j.1600-0722.2002.21275.x

MCKENZIE, M. A.; LINDEN, R. W.; NICHOLSON, J. W. The physical properties of conventional and resinmodified glass-ionomer dental cements stored in saliva, proprietary acidic beverages, saline, and water.

Biomaterials, v. 24, n. 22, p. 4063-4069, 2003. https://doi.org/10.1016/S0142-9612(03)00282-5

MEENAKSHI; MAHESHWARI, R. C. Fluoride in drinking water and its removal. Journal Of Hazardous Materials, v. 137, n. 1, p. 456-463, 2006. https://doi.org/10.1016/j.jhazmat.2006.02.024

MOREAU, J. L.; XU, H. H. Fluoride releasing restorative materials: Effects of $\mathrm{pH}$ on mechanical properties and ion release. Dental Materials, v. 26, n. 11, p. e227-35, 2010. https://doi.org/10.1016/j.dental.2010.07.004

MUNGARA, J.; PHILIP, J.; JOSEPH, E.; RAJENDRAN, S.; ELANGOVAN, A.; SELVARAJU, G. Comparative evaluation of fluoride release and recharge of pre-reacted glass ionomer composite and nanoionomeric glass ionomer with daily fluoride exposure: an in vitro study. Journal of Indian Society of Pedodontics and Preventive Dentistry, v. 31, n. 4, p. 234-239, 2013. https://doi.org/10.4103/09704388.121820

NAOUM, S.; ELLAKWA, A.; MARTIN, F.; SWAIN, M. Fluoride release, recharge and mechanical property stability of various fluoride-containing resin composites. Operative Dentistry, v. 36, n. 4, p. 422-432, 2011. https://doi.org/10.2341/10-414-L

NEELAKANTAN, P.; JOHN, S.; ANAND, S.; SURESHBABU, N.; SUBBARAO, C. Fluoride release from a new glass-ionomer cement. Operative Dentistry, v. 36, n. 1, p. 80-85, 2011. https://doi.org/10.2341/10-219LR

PRESTON, A. J.; AGALAMANYI, E. A.; HIGHAM, S. M.; MAIR, L. H. The recharge of esthetic dental restorative materials with fluoride in vitro - two years' results. Dental Materials, v. 19, n. 1, p. 32-37, 2003. https://doi.org/10.1016/S0109-5641(02)00011-8

SHIOZAWA, M.; TAKAHASHI, H.; IWASAKI, N. Fluoride release and mechanical properties after 1-year water storage of recent restorative glass ionomer cements. Clinical oral investigations, v. 18, n. 4, p. 10531060, 2014. https://doi.org/10.1007/s00784-013-1074-4

SIDHU, S. K. Glass-ionomer cement restorative materials: a sticky subject? Australian Dental Journal, v. 56 Suppl 1, p. 23-30, 2011. https://doi.org/10.1111/j.1834-7819.2010.01293.x

SILVA, R. C.; ZUANON, A. C. C.; ESBERARD, R. R.; CANDIDO, M. S. M.; MACHADO, J. S. In vitro microhardness of glass ionomer cements. Journal of Materials Science: Materials in Medicine, v. 18, n. 1, p. 139-142, 2007. https://doi.org/10.1007/s10856-006-0672-y

SIVASAMY, A.; SINGH, K. P.; MOHAN, D.; MARUTHAMUTHU, M. Studies on defluoridation of water by coal-based sorbents. Journal of Chemical Technology \& Biotechnology, v. 76, n. 7, p. 717-722, 2001. https://doi.org/10.1002/jctb.440

WANG, X. Y.; YAP, A. U.; NGO, H. C.; CHUNG, S. M. Environmental degradation of glass-ionomer cements: a depth-sensing microindentation study. Journal of Biomedical Materials Research Part B: Applied Biomaterials, v. 82, n. 1, p. 1-6,2007. https://doi.org/10.1002/jbm.b.30697

WIEGAND, A.; BUCHALLA, W.; ATTIN, T. Review on fluoride-releasing restorative materials--fluoride release and uptake characteristics, antibacterial activity and influence on caries formation. Dental Materials, v. 23, n. 3, p. 343-362, 2007. https://doi.org/10.1016/j.dental.2006.01.022 
Evaluation of mechanical... $\quad$ GUMUSTAS, B.; YAMAN DOSDOĞRU, E.; GÜNEYSU, S.

WILDE, M. G. K.; DELFINO, C. S.; SASSI, J. F.; GARCIA, P. P. N. S.; PALMA-DIBB, R. G. Influence of $0.05 \%$ sodium fluoride solutions on microhardness of resin-modified glass ionomer cements. Journal of Materials Science-Materials in Medicine, v. 17, n. 9, p. 869-873, 2006. https://doi.org/10.1007/s 10856-0069847-9

XIE, D.; BRANTLEY, W. A.; CULBERTSON, B. M.; WANG, G. Mechanical properties and microstructures of glass-ionomer cements. Dental Materials, v. 16, n. 2, p. 129-38, 2000. https://doi.org/10.1016/S01095641(99)00093-7

XU, X. M.; BURGESS, J. O. Compressive strength, fluoride release and recharge of fluoride-releasing materials. Biomaterials, v. 24, n. 14, p. 2451-2461, 2003. https://doi.org/10.1016/S0142-9612(02)00638-5

YADAV, A. K.; KAUSHIK, C. P.; HARITASH, A. K.; KANSAL, A.; RANI, N. Defluoridation of groundwater using brick powder as an adsorbent. Journal of Hazardous Materials, v. 128, n. 2-3, p. 289-293, 2006. https://doi.org/10.1016/j.jhazmat.2005.08.006 